\title{
Potable Water in the United States, Contaminants and Treatment: A Review
}

\author{
Kaleh Karim ${ }^{1,2}$, Sujata Guha1, Ryan Beni ${ }^{*}$ \\ ${ }^{1}$ Department of Chemistry, Tennessee State University, Nashville, TN, USA \\ ${ }^{2}$ Department of Biological Sciences, Tennessee State University, Nashville, TN, USA \\ Email: *rbeni@tnstate.edu
}

How to cite this paper: Karim, K., Guha, S., \& Beni, R. (2020). Potable Water in the United States, Contaminants and Treatment: A Review. Voice of the Publisher, 6, 183198. https://doi.org/10.4236/vp.2020.64022

Received: September 18, 2020

Accepted: December 28, 2020

Published: December 31, 2020

Copyright (c) 2020 by author(s) and Scientific Research Publishing Inc. This work is licensed under the Creative Commons Attribution International License (CC BY 4.0).

http://creativecommons.org/licenses/by/4.0/ (c) (i) Open Access

\begin{abstract}
Potable water is a basic need for humans, but attaining clean drinking water is a significant challenge for many developing and underdeveloped countries around the globe. In the United States, potable water is obtained from ground and surface sources and treated with various chemicals to meet federal and state standards, prior to its delivery to consumers. The United States Environmental Protection Agency (EPA) has established standards for the maximum level of contaminants (MCLs) to regulate their amounts in the public drinking water. Raw water can be compromised of physical, chemical, and biological contaminants and can pose a health burden among immunocompromised individuals such as elderly, pregnant women, and especially children. The EPA publishes a contaminant candidate list (CCL) every five years. However, many of the drinking water regulations were established decades ago. This review aims to explore factors impacting water safety, processes used to purify water, the by-products that might remain after the purification process, and their impact on the health of the general populace, especially the immunocompromised individuals. In addition to the multibarrier water treatment process, ultraviolet treatment is also evaluated to determine its benefits and limitations.
\end{abstract}

\section{Keywords}

Potable Water, Water Contaminants, Water Treatment, Drinking Water, Lead, Copper, Ultraviolet Treatment

\section{Introduction}

Potable water is defined as water that is clean and safe for consumption. Water is an essential nutrient and attaining clean, contaminant free water is a public health matter, as waterborne pathogens and contaminants can pose a serious physical 
and financial burden on the general populace, especially among immunocompromised individuals. Although only a small portion of the tap water is used for consumption, all tap water in the United States must meet the Environmental Protection Agency (EPA) standards. The EPA was established by the former US president Richard Nixon and began to operate in 1970 following President Nixon's executive order (EPA, Web Archives, 2016) in response to the increasing public pressure over environmentalism and the need for conservation (Rinde, 2017; EPA Historical Publication, 1992).

The EPA implements numerous legislations and serves as the authority in the "Clean air Act", "Emergency Planning and Community Right-to-know Act", "Federal Insecticide and Recovery Act", Toxic Substances Control Act", "Federal Insecticide, Fungicide, and Rodenticide Act", and the "Safe Drinking Water Act". The Safe Drinking Water Act (SDWA) was passed by the US congress in 1974, and is one of the legislations that directly impact the general populace on a daily basis, as it provides standards for over 150,000 public water utility systems across the United States (SDWA, 2017). The EPA drinking water standards must be implemented by every public water system (PWS) in the United States. However, over forty million individuals who rely on private wells as their main source for drinking water (Dieter \& Maupin, 2017) are not covered under the SDWA (EPA, 2017).

To ensure that drinking water is safe and contaminant free, the EPA provides a contaminant candidate list (CCL) and updates it, periodically documenting recent water contaminants and publishing the list every five years (EPA, 2016). The contaminants include various chemicals and pharmaceuticals, microorganisms, and radiological waste (US EPA, 2018). Since water is not packaged and is consumed raw, leading to microorganisms posing a significant public health concern, the Food and Drug Administration (FDA) regulated bottled water under the 1938's Federal Food, Drug, and Cosmetic Act (United States FDA, 1938). However, tap water remains to be is regulated by the EPA.

Sources for potable water include surface water (rivers, lakes, and reservoirs) and groundwater (aquifers). Groundwater and surface water are not isolated systems and are continually recharged by each other, as well as by rain and other natural sources of precipitation. These sources can become contaminated by waste water during flooding, and can have a significant impact on the management of water source (Kundzewics et al., 2014). Extreme weather conditions can also cause chemical contaminants to become more concentrated in very hot seasons and become more dilute during rainy seasons. In the United States, majority of the drinking water is obtained from surface water source (Table 1), while only approximately $13 \%$ of states utilize groundwater as their main drinking water source (Figure 1).

\section{Conceptual Framework}

This research is conducted to evaluate the current water treatment procedures 
Table 1. Major drinking water sources in major cities in United States.

\begin{tabular}{|c|c|c|c|}
\hline State & Drinking Water Source & State & Drinking Water Source \\
\hline Alabama & Potomac River & Montana & Missouri River \\
\hline Alaska & Eklutna Lake & Nebraska & Platte River \\
\hline Arizona & Salt and Verde Rivers & Nevada & Kings Creek, Ash Creek and Marlette \\
\hline Arkansas & Lake Winona and Lake Maumelle & New Hampshire & Bellamy Reservoir \\
\hline California & Sacramento and American River & New Jersey & Kittatinny Aquifer \\
\hline Colorado & Strontia Springs & New Mexico & Bernalillo Rivers and Creeks \\
\hline Connecticut & Farmington River & New York & Delaware River and Croton and Catskill Aqueduct \\
\hline Delaware & $\begin{array}{l}\text { Brandywine, White Clay and Red } \\
\text { Clay creeks and reservoirs }\end{array}$ & North Carolina & Falls Lake Reservoir \\
\hline Florida & Floridan Aquifer & North Dakota & Red River \\
\hline Georgia & Chattahoochee River & Ohio & Scioto River \\
\hline Hawaii & Haiku Tunnel and Well & Oklahoma & Canton Lake and McGee Creek \\
\hline Idaho & Boise River & Oregon & Clear Creek \\
\hline Illinois & Lake Springfield & Pennsylvania & Schuylkill River \\
\hline Indiana & Teays River Valley & Rhode Island & Scituate Reservoir \\
\hline Iowa & Raccoon and Des Moines River & South Carolina & Lake Keowee \\
\hline Kansas & Kansas River & South Dakota & $\begin{array}{c}\text { Big Sioux, Big Sioux Aquifer and Middle } \\
\text { Skunk Creek Aquifer }\end{array}$ \\
\hline Kentucky & Old Hickory Lake & Tennessee & Cumberland River \\
\hline Louisiana & Southern Hills Aquifer & Texas & Lake Austin \\
\hline Maine & China Lake & Utah & Cottonwood Creek \\
\hline Maryland & Magothy, Upper and Lower Patapsco Aquifers & Vermont & Berlin Pond \\
\hline Massachusetts & Ware River & Virginia & James River \\
\hline Michigan & Saginaw Sandstone Aquifer & Washington & Cedar River \\
\hline Minnesota & Mississippi River & West Virginia & Elk River \\
\hline Mississippi & Pearl River & Wisconsin & Lake Michigan \\
\hline Missouri & Missouri River & Wyoming & Granite Springs Reservoir \\
\hline
\end{tabular}

\section{Drinking water source distribution in USA}

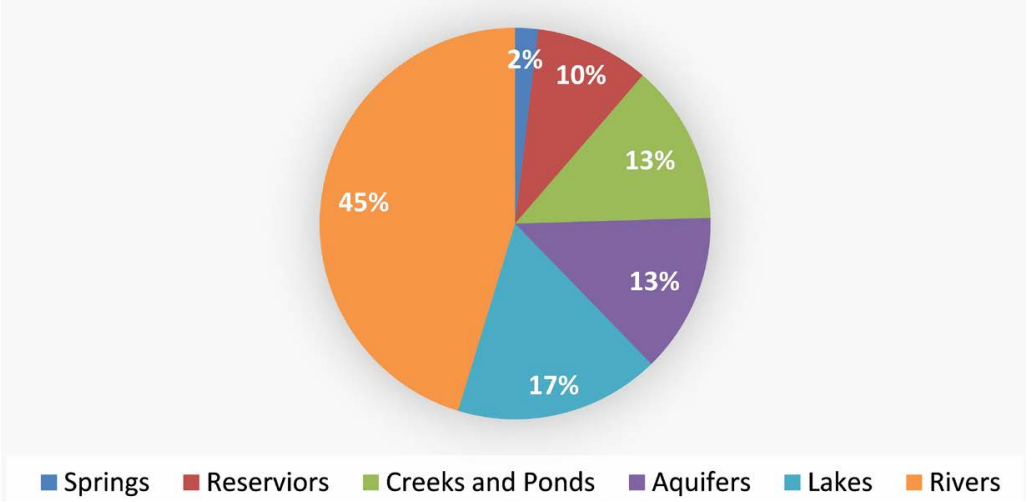

Figure 1. Drinking water source distribution: Majority of the states utilize surface water as their main source of drinking water. 
undertaken in the US water treatment facilities. To understand the purpose to these procedures, the quality and composition of raw water must be examined. In the United States, drinking water is obtained from spring, reservoirs, creeks, ponds, aquifers, lakes, and rivers. However, the water treatment procedures are largely uniform across all facilities, regardless of where raw water is obtained. Following the water treatment procedure, secondary contaminants are also evaluated to determine the health burden and consequences associated with exposure. In addition, we evaluate the roles of the water quality monitoring agencies, their efficacy, as well as their means of communication.

\section{Methods}

This research utilized textbooks, journal articles, information from regulatory agencies, and data from water facility websites to obtain water quality information for different states. Telephone interviews were also conducted with workers in water treatment facilities in various states. Additionally, interviews were conducted with water facility superintendents in and around the city of Nashville, Tennessee to gather information about water quality.

\section{Literature Review}

\subsection{Contaminants}

Many factors can compromise drinking water quality, including human waste, polluting agents, radiological waste material, industrial wastes, and infectious agents. The EPA has regulated standards for six different groups of contaminants, which all together account for over 90 contaminants as shown in Table 2 (NPDWR, 2017). Many contaminants are not strictly regulated despite EPA's recommended standards (NPDWR, 2017). Aluminum, chloride, fluoride, iron, manganese, sulfate, and zinc are some of the chemicals that are used regularly in the water treatment process leaving residuals but these residuals are rarely reported.

Table 2. Water contaminant groups.

\begin{tabular}{|c|c|}
\hline Group & Contaminants \\
\hline Microorganisms & Giardia lamblia, Cryptosporidium, Legionella, Total Coliform (including E. coli and fecal coliform), and viruses \\
\hline & $\begin{array}{l}\text { Acrylamide, alachlor, atrazine, benzene, carbofuran, carbon tetrachloride, chlordane, chlorobenzene, dalapon, various } \\
\text { forms of dichlorobenzene, dichloroethane, dichloroethylene, dichloromethane, dichloropropane, dinoseb, dioxin, diquat, }\end{array}$ \\
\hline Organic Chemicals & $\begin{array}{l}\text { endothall, endrin, epichlorohydrin, ethylbenzene, ethylene dibromide, glyphosate, heptachlor, hexachlorobenzene, lindane, } \\
\text { methoxychlor, osamyl, polychlorinated biphenyls, pentachlorophenol, picloram, simazine, styrene, tetrachloroethylene, } \\
\text { toluene, toxaphene, various forms of trichlorobenzene, trichloroethane, trichloroethylene, vinyl chloride and xylenes. }\end{array}$ \\
\hline Inorganic Chemicals & $\begin{array}{l}\text { Antimony, arsenic, asbestos, barium, beryllium, cadmium, chromium, copper, cyanide, fluoride, lead, mercury, nitrate, } \\
\text { nitrite, selenium and thallium. }\end{array}$ \\
\hline Disinfectants & Chloramines, chlorine, and chlorine dioxide. \\
\hline Disinfectant Byproducts & $\begin{array}{l}\text { Bromate, chlorite, haloacetic acids and total trihalomethanes (bromoform, chloroform, bromodichloromethane, } \\
\text { dibromochloromethane) }\end{array}$ \\
\hline
\end{tabular}




\subsubsection{Physical Contaminants}

Turbidity, measure in nephelometric turbidity unit (NTU), is the main source of physical contaminant in raw water. This measure of cloudiness and is attributed to a significant amount of invisible particles that arise from agriculture, mining, and stormwater runoff. The World Health Organization (WHO), and the US EPA recommend that turbidity levels must not exceed 5 NTU (Lenntech, 2019; WHO, 2017; US EPA, 2019). Various reagents are used to reduce turbidity. One of the most commonly used chemicals is aluminum sulfate $\left(\mathrm{Al}_{2}\left(\mathrm{SO}_{4}\right)_{3} \cdot \mathrm{nH}_{2} \mathrm{O}\right)$ also known as Alum among the PWS community. However, poly-aluminum chloride $\left(\mathrm{AlCl}_{3}\right)$, ferric chloride $\left(\mathrm{FeCl}_{3}\right)$ and gypsum $\left(\mathrm{CaSO}_{4} \cdot 2 \mathrm{H}_{2} \mathrm{O}\right)$ are also utilized [14].

\subsubsection{Biological Contaminants}

Drinking water systems are susceptible to the growth of many microorganisms, including those found in fecal matter such as Campylobacter ssp., Cryptosporidium parvum, and rotavirus, in addition to Legionella ssp. (Szewzyk et al., 2000). Collectively, water-borne pathogens were responsible for 1006 illnesses between 2013 and 2014 (Benedict et al. 2017). The EPA has set regulations to prevent human infection from the ingestion of the microorganisms and bacteria from pathogens, such as Cryptosporidium, Giardia lamblia, Legionella, and total Coliform, which include fecal coliform and E. coli (EPA, 2018). Cryptosporidium and Giardia lamblia are both parasites which enter the water system from animal and human feces and can cause diarrhea, stomach cramps, vomiting and other gastrointestinal illnesses and are not responsive to bleaching (Sponseller et al., 2014; Despommier et al., 2019; CDC, 2020). Legionella and E. coli are both gram-negative bacteria and are intrinsically present in water and are responsible for Pontiac fever which resembles the flu (WHO, 2007). To combat these pathogens, many water treatment facilities use chlorine to disinfect water.

Although the drinking water industry has used chlorine dioxide $\left(\mathrm{ClO}_{2}\right)$ to disinfect water, over the years, several facilities have adopted the use of liquid chlorine bleach, to ensure drinking water industry worker safety and limited exposure to toxic fumes (ATSDR, 2004; OSHA, 2012). $\mathrm{ClO}_{2}$ has been shown to be more effective in killing pathogens, controlling microbiological regrowth, and biofilm control (Gagnon et al., 2005).

\subsubsection{Chemical Contaminants}

With industrial and population growth, waste disposal has become a growing concern. Industrial and radiological waste can find their way into the drinking water source. Organic and inorganic chemicals can be an intrinsic part of raw water, or they can enter the waterways as runoff from agricultural or chemical industries. However, various chemicals such as coagulants, odor control agents, and corrosion control agents enter drinking water as a result of water treatment processes. Disinfectants are added as an extrinsic factor to reduce microorganisms and improve water quality. However, these disinfectants leave by-products which cannot be eliminated prior to consumption. Hence, the chemicals can be 
divided into two groups; those pre-existent in raw water (intrinsic factors) and those added (remain in the water as by-products) to remove pre-existing compounds. Intrinsic chemicals include minerals such as calcium and magnesium which contribute to hardness are the manifestation of minerals as water percolates through limestone (NGWA, 2020). Other chemicals also enter water sources as runoffs from herbicides, chemical plants, termiticide, agricultural chemical factories, discharge from drug and chemical factories, rubber factories and petroleum refineries, as well as wastewater treatment plants. These chemicals can be organic or inorganic in nature, and usually are toxic (Laws, 2018). Some of the chemicals comprising raw water source are listed in Table 2.

In addition to the chemical contaminant as a result of human activity, chemicals added during the water treatment process can also leave residuals and decrease water quality. Chlorine is a halogen gas, or calcium hypochlorite are highly toxic to pathogens, such as bacteria, viruses, and protozoans are used to disinfect water (Calderon, 2000). Chlorination process was first published in 1894 and implemented in 1897 in Maidstone, England to combat the Typhoid epidemic that killed 132 people and was first implemented as a continuous practice for eradication of waterborne pathogens in New Jersey, USA in 1908 and across the world (Turneaure \& Russel, 1901; Leal et al., 1909; Hazen, 1916). Studies have shown the impact of elevated chlorine by-products on human health, including an increased risk of miscarriages (Leoni et al., 1989; Pathak et al., 2009) infertility (Den Hond et al., 2006), and even cancer (International Agency for Research on Cancer, 1990). Trihalomethanes, such as dibromochloromethane, bromodichloromethane, and bromoform, arise from the reaction of chlorine or bromine with organic compounds present in the water. Continuous exposure to dibromochloromethane and bromoform has been associated with kidney and liver cancer, colorectal cancer, bladder cancer, lung cancer, in addition to heart disease and even death at high exposure (ATSDR, 2011; Flaten, 1992; Morris et al., 1992; Yang et al., 1998; Guha et al., 2019).

Although addition of $\mathrm{ClO}_{2}$ gas was a common practice to control microorganism growth and regrowth, many facilities have started to make their own chlorine bleach. Water treatment facilities either purchase liquid chlorine or produce chlorine within their facility as follows:

$$
\mathrm{NaCl}+\mathrm{H}_{2} \mathrm{O} \stackrel{\text { Electricity }}{\longrightarrow} \mathrm{NaOCl}_{\text {(liquid) }}+\mathrm{H}_{2 \text { (gas) }}
$$

Sodium chloride is mixed with deionized water along with electricity to produce sodium hypochlorite (which is stored and used as a disinfectant) and hydrogen, gas which is released into the environment. Potassium permanganate $\left(\mathrm{KMnO}_{4}\right)$ is also added to raw water to control odor and improve taste brought about due to algae growth in the raw water source. This practice was adopted following an incident in Cedar River, Iowa in May 1962, when drinking water taste was affected significantly due to major floods that occurred earlier that year (Cherry, 1962).

$4 \mathrm{KMnO}_{4}+2 \mathrm{H}_{2} \mathrm{O} \rightarrow 4 \mathrm{MnO}_{2}+3 \mathrm{O}_{2}+4 \mathrm{KOH}$ 
Potassium permanganate has a purple color and has a sweet taste (PubChem, 2019). It reacts with water to produce manganese oxide, oxygen, and potassium hydroxide. $\mathrm{KMnO}_{4}$ is effective in decreasing iron concertation and improving taste and odor in water. However, ingesting small amounts of $\mathrm{KMnO}_{4}$ above 200 $\mathrm{mg} / \mathrm{L}$ can cause gastrointestinal issues (Wilhite et al., 2012).

Furthermore, hydrogen peroxide $\left(\mathrm{H}_{2} \mathrm{O}_{2}\right)$ is added to water to eliminate cryptosporidium in the oocyst stage, as they can be resistant to chlorine at this stage (Ramsay et al., 2014). Due to its thermodynamic instability, $\mathrm{H}_{2} \mathrm{O}_{2}$ decomposes into water and oxygen readily, leaving no by-products.

The EPA requires lead levels to remain below 15 parts per billion and copper levels below 1300 parts per billion in drinking water (EPA, 2018; EPA et al., 1970). Lead has been shown to cause poor cognition, and no amount of lead has been deemed to be safe. Studies have shown that even low levels of lead can burden the body and impair normal cognitive function in children, and has been associated with behavioral and learning disorders (Yousef et al., 2013; Nigg et al., 2007; Feldman \& White, 1992). To reduce the corrosion, anti-corrosive reagent (zinc orthophosphate) is added during the treatment process adding to list of chemicals entering water.

In recent years, hydraulic fracturing also called fracking has raised the concerns about the pollution of water in many countries including Canada, New Zealand, South Africa, Ukraine, United Kingdom and the United States. The fracking is a well stimulation technique involving the fracturing of bedrock formations by a pressurized liquid (Gandossi \& Von Estorff, 2015). The process involves the high-pressure injection of "fracking fluid" (primarily water, containing sand or other proppants suspended with the aid of thickening agents) into a wellbore to create cracks in the deep-rock formations through which natural gas, petroleum, and brine will flow more freely. When the hydraulic pressure is removed from the well, small grains of hydraulic fracturing proppants (either sand or aluminium oxide) hold the fractures open.

Hydraulic fracturing is highly controversial (World Energy Outlook Special Report, 2013). Groundwater becomes contaminated by hydraulic fracturing in a number of ways, including leakage from liquid storage areas, leakage from injection wells, leakage during hydrofracking along faults or up abandoned wells, seepage into the ground when wastewater and residuals are applied to land (i.e. used for irrigation or on roads for dust suppression or de-icing), and other means.

In order to frack, an enormous amount of water is mixed with various toxic chemical compounds to create frack fluid. This frack fluid is further contaminated by the heavy metals and radioactive elements that exist naturally in the shale. A significant portion of the frack fluid returns to the surface, where it can spill or be dumped into rivers and streams. Underground water supplies can also be contaminated by fracking, through migration of gas and frack fluid underground. Once the frack fluid mixture is injected into the ground it can also pick up or entrain further contaminants, like radium, a cancer-causing radioactive 
particle found deep within the Marcellus and other shales (Facking's Environmental Impacts: Water, 2015).

\subsection{Water Treatment Process}

Raw water is extracted from a primary water source (lakes, rivers, or aquifers) and subject to a long treatment process prior to being made available for public use. However, EPA has established regulations to mitigate health problems associated with contaminants present in water (Clever et al., 2000). The treatment process includes coagulation and flocculation process to reduce turbidity, followed by sedimentation and sand or rapid filtration, to remove any dense matter that may have remained after the coagulation process (Simpson, 2008; Hwang et al., 2012). The most standard form of water treatment in the United States involves the use of $\mathrm{Al}_{2}\left(\mathrm{SO}_{4}\right)_{3} \cdot 14 \mathrm{H}_{2} \mathrm{O}$ or Alum, which acts as a coagulant. When mixed with water, various by-products or residuals are formed, according to the following reaction, leading to the formation of aluminum hydroxide, hydrogen ion, sulfate ion, and water:

$$
\mathrm{Al}_{2}\left(\mathrm{SO}_{4}\right)_{3} \cdot 14 \mathrm{H}_{2} \mathrm{O} \rightarrow 2 \mathrm{Al}(\mathrm{OH})_{3}+6 \mathrm{H}^{+}+3 \mathrm{SO}_{4}^{2-}+8 \mathrm{H}_{2} \mathrm{O}
$$

During flocculation turbidity is reduced to a desirable amount depending on the $\mathrm{pH}$, and initial turbidity reducing up to $70 \%$ of total organic compounds (Aragonés-Beltrán et al., 2009; Jiang, 2015; Ayekoe et al., 2017). Aluminum reacts with water to yield aluminum hydroxide (solid) along with sulfate. Although the usage of alum is a standard procedure for water treatment, the EPA does not regulate or mandate the regulation of sulfate in drinking water.

Finally, the water is disinfected, prior to being distributed to the consumer, via chlorination or chloramination (Simpson, 2008; Hwang et al., 2012). The general scheme for water treatment process is summarized in Figure 2. In some facilities, water is chlorinated prior to and after filtration, while in others, the disinfection process precedes the filtration process.

In 1829, Chelsea WaterWorks company was the first public water system to

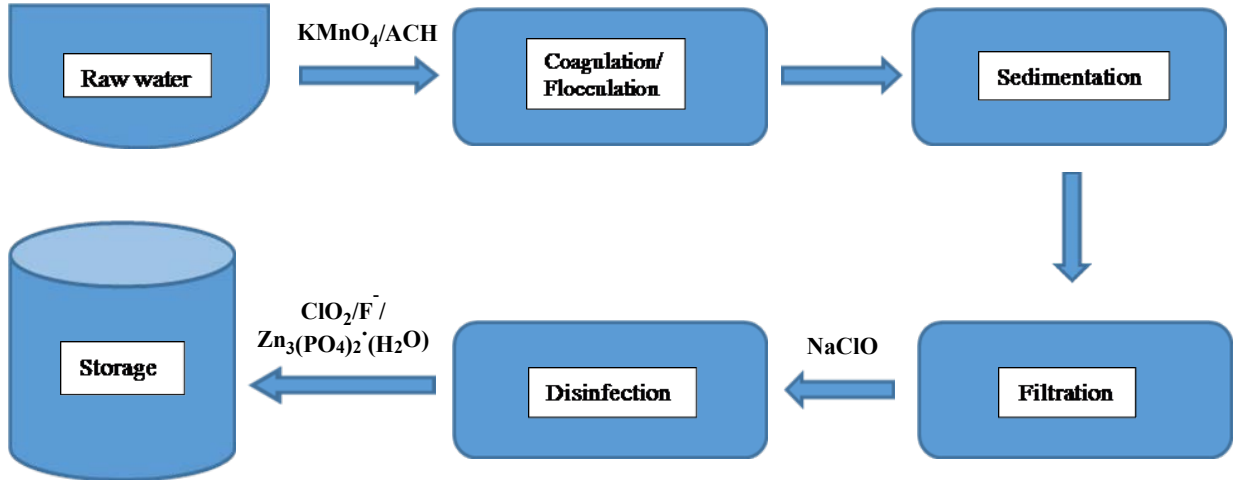

Figure 2. General scheme of water treatment process. Each water treatment facility utilizes a slightly different process however, majority of plants use this general process. $\mathrm{ClO}_{2}$ gas was generally used for the disinfection process however, many plants have started to generate chlorine at their plants. 
utilize sand filtration and chlorination for water treatment (Christman, 1998; Huisman \& Wood, 1974). Varying types of filtration systems are currently used, which include slow sand filter beds, and rapid sand filters or membrane filtration, often through reverse osmosis (Huisman \& Wood, 1974; National Drinking Water Clearinghouse, 2000). Slow sand filtration is thought to be highly effective in reducing $90 \%$ - 99\% of the contaminants, but requires a significant amount of filter media spread over a large surface area, and manual labor for everyday maintenance, since water turbidity can clog the filter while rapid sand filtration requires less land area, is less susceptible to clogging from turbid water, due to coarse sand granules, and the filtration process is faster (National Drinking Water Clearinghouse, 2000; American Water Works Association, 2003; US EPA, 1990). Reverse osmosis is most effective in reducing chemicals and microorganisms and functions by applying pressure to pass water through a thin membrane against its natural flow, hence, trapping contaminants inside the membrane producing contaminant-free water for consumption but this process is not efficient for mass water purification (Malaeb \& Ayoub, 2011). Finally, potable water is distributed to households by pipes, composed of metal, plastic, or cement which play a significant roles in the formation and proliferation of microbials, post purification of the water source (Niquette et al., 2000; Pinto et al., 2012). Internal portion of the piping systems provides a good niche for the formation of bacterial biofilm, especially where the iron piping material is corrodes (Van Der Kooij et al., 1995; LeChevallier et al., 1993; Jang et al., 2011; Yu et al., 2010). Based on evidence, PVC is a better alternative to traditional metal based pipes due to reduced microbial growth depending on environmental factors (Hwang et al., 2012; Niquette et al., 2000; Wang et al., 2014; McCoy \& Van Briesen, 2012).

\subsection{Ultraviolet Treatment}

Ultraviolet (UV) radiation, of wavelength $10-400 \mathrm{~nm}$, is naturally present in sunlight at low concentrations, and accounts for approximately ten percent of the electromagnetic radiation produced by the sun. The disinfectant properties of ultraviolet radiation were first discovered in 1887 . However, UV radiation was first utilized for water treatment in 1910 in Marseilles, France (U.S. Army Public Health Command, 2011) and in the early 1900s in the United States. Ultraviolet photolysis has been shown to be highly effective in the degradation of pesticides (with the exception of isoproturon) (Sanches et al., 2009); pharmaceuticals such as ibuprofen and diclofenac; endocrine disruptors; and microorganisms such as Giardia lamblia cysts and Cryptosporidium oocysts, when used in conjugation with hydrogen peroxide (Kruithof et al., 2007). Although UV treatment is an effective alternative for reducing microbials in drinking water, studies have shown that $E$. coli is able to undergo photo-repair following exposure to ultraviolet treatment at lower pressures (Zimmer \& Slawson, 2002).

UV treatment, although expensive and hard to maintain, is important because 
it helps to eliminate many contaminants with minimal to no use of chlorine. This benefit, combined with the lack of bromate formation, is an added advantage to using UV. Currently, UV treatment is used in newer facilities and those that have sufficient funding to add UV treatment to their existing water treatment facility. However, to implement UV radiation, one must evaluate the disadvantages to UV technology. In addition to cost and maintenance, UV treatment is not effective with turbid water, although it can serve as an additional barrier following coagulation, flocculation, and sedimentation processes. In addition, because UV radiation is a timed process, microorganisms may be able to repair the DNA and start to contaminate water post the radiation process, while chlorine remains in the water until it is distributed to the consumer.

\section{Results and Discussion}

Upon reviewing different raw water sources, it was determined that the majority of water is obtained from surface water, which is more susceptible to pollutants from human activity, as well as human and industrial waste. When surface water first enters the water treatment facility, turbidity is the major concern, as it reduces the quality, taste and smell of water. In addition, turbid water does not respond well to filtration, as small particles present in the turbid water can clog filtration membranes. Hence, it is necessary to reduce turbidity prior to the filtration process. However, because each water body varies in the level of turbidity, some water treatments my use more or less coagulants depending on the level of turbidity. The more turbid the raw water source, the more alum is required, which will increase the likelihood that there will be more aluminum residuals in the resulting water. Because turbidity tends to fluctuate depending on the levels of precipitation, water quality may also fluctuate during different seasons.

During the interview process, it was determined that, although each facility monitors their own drinking water, federal level monitoring is not always enforced strictly. In Smyrna, Tennessee, it was determined that the water treatment facility was not able to upload water monitoring results for as long as six months, in 2019, due to the EPA website malfunction. These malfunctions can jeopardize water quality because, when the authoritative agency is not responsive, water treatment facilities may not adhere to the required safety standards. Hence, it is necessary for independent local and state level inspecting agencies to regularly monitor water quality.

Additionally, when speaking to the average citizens, it was determined that many of them lacked knowledge regarding the water treatment process. Many water treatment facilities have established regular and very beneficial facility tours; however, these tours do not allow documentation or photography of their facility. Upon speaking to water treatment facility superintendents, it was determined that iron $(\mathrm{Fe})$ is retained in the predominant piping material due to it durability. In addition, the city of Nashville, Tennessee, has piping material made of concrete, iron, and even wood. This demonstrates the aging and crippling in- 
frastructure among older cities and the possible need for upgrading with more state-of-the-art technology to ensure that these cities obtain and sustain high quality water.

\section{Recommendations}

Based on the results of this study, the following recommendations are made to enhance the quality of water and ensure that all citizens have access to safe potable water.

1) Different bodies of water should be evaluated independently and alternative treatment procedures must be adopted for less polluted water to avoid the introduction of too many chemicals, in an effort to purify an already clean water.

2) Continuous monitoring of treated water is essential in determining how water quality fluctuates in different seasons.

3) Establishing city-based and state-based independent monitoring procedures are necessary to ensure that regulations are adequately enforced.

4) More legislation is necessary to ensure that rural areas have excess to contaminant-free water.

5) Educational programs are required to ensure that citizens remain well-informed about the quality of water being consumed, in addition to the health of their raw water source.

6) A thorough review of water infrastructure in each state should be undertaken, and updated, if necessary.

7) Increased mandatory inspection of secondary contaminants such as sodium, chlorine, and aluminum residuals are necessary.

\section{Conclusion}

Raw water is not safe for human consumption, due to the presence of intrinsically present contaminants. Multistep procedures are implemented, along with the addition of various chemicals, to ensure that water is clean and safe to drink. These reagents may leave behind residuals or by-products that may be hazardous to human health. Raw water turbidity is reduced by using aluminum sulfate or another coagulant. Chlorine, hydrogen peroxide, carbon dioxide, calcium hydroxide, potassium permanganate, and sodium hypochlorite are some of the other chemicals added to raw water to reduce pathogens, improve taste, reduce odor, neutralize $\mathrm{pH}$, and increase water clarity. Water treatment facilities must adhere to federal and state regulations, to provide contaminant-free water to consumers. However, there is scientific evidence, as outlined in this review, that demonstrate the health risks associated with chlorination, presence of lead, and potassium permanganate. In addition, disinfectants may react with other organic materials to form by-products, which have also been shown to increase the chance of developing cancer as well as developmental and reproductive issues. In addition to chemical by-products used in the water treatment process, heavy metals can also enter drinking water, as a result of eroding household plumbing. Pro- 
longed exposure to these heavy metals has been associated with adverse health effects, especially in reducing cognitive function in children. The most concerning of these chemicals is chlorine and its increased usage, which has been the only barrier against microbial growth. Elevated chlorine levels have been associated with reproductive abnormalities, fertility issues, and even cancer. In addition, chlorine by-products can also react with humic and fulvic acid to yield trihalomethanes. To mitigate the hazards associated with chlorine use, UV radiation has proven to be a promising treatment. Ultraviolet radiation has been shown to eliminate pathogens and break down micropollutants, such as pharmaceuticals and pesticides. The benefits of UV treatment are becoming increasingly popular in many water treatment facilities in the United States that can afford to add this innovative technology with the financial means to maintain it. Although there are risks associated with various chemicals and by-products during the water treatment process, the benefits far outweigh the risks posed by consuming raw and contaminated water. Continued research is empirical in improving the water treatment process to ensure that all people have access to safe drinking water, free from pathogens, harmful chemicals, and by-products.

\section{Conflicts of Interest}

The authors declare no conflicts of interest regarding the publication of this paper.

\section{References}

Agency for Toxic Substances and Disease Registry (ATSDR) (2011). Public Health Statement: Bromoform \& Dibromochloromethane. https://www.atsdr.cdc.gov/phs/phs.asp?id=711\&tid=128

American Water Works Association (2003). Water Treatment (3rd ed., p. 117). Denver, CO: American Water Works Association.

Aragonés-Beltrán, P., Mendoza-Roca, J. A., Bes-Piá, A., García-Melón, M., \& Parra-Ruiz, E. (2009). Application of Multicriteria Decision Analysis to Jar-Test Results for Chemicals Selection in the Physical-Chemical Treatment of Textile Wastewater. Journal of Hazardous Materials, 164, 288-295. https://doi.org/10.1016/j.jhazmat.2008.08.046

ATSDR (2004). Toxic Substances Portal-Chlorine Dioxide \& Chlorite. https://www.atsdr.cdc.gov/toxfaqs/tf.asp?id=581\&tid=108

Ayekoe, C. Y. P., Robert, D., \& Lanciné, D. G. (2017). Combination of CoagulationFlocculation and Heterogeneous Photocatalysis for Improving the Removal of Humic Substances in Real Treated Water from Agbô River (Ivory-Coast). Catalysis Today, 281, 2-13. https://doi.org/10.1016/j.cattod.2016.09.024

Benedict, K., Reses, H., Vigar, M., Roth, D., Roberts, V., Mattioli, M., Cooley, L., Hilborn, E., Wade, T., Fullerton, K., Yoder, J., \& Hill, V. (2017). Surveillance for Waterborne Disease Outbreaks Associated with Drinking Water-United States, 2013-2014. Morbidity and Mortality Weekly Report (MMWR), 66, 1216-1221. https://doi.org/10.15585/mmwr.mm6644a3

Calderon, R. L. (2000). The Epidemiology of Chemical Contaminants of Drinking Water. Food and Chemical Toxicology, 38, 13-20. https://doi.org/10.1016/S0278-6915(99)00133-7 
Centers for Disease Control and Prevention (CDC) (2020). Parasites-Giardia. https://www.cdc.gov/parasites/giardia/index.html

Cherry, A. (1962). Use of Potassium Permanganate in Water Treatment. American Water Works Association, 54, 417-424. https://doi.org/10.1002/j.1551-8833.1962.tb00862.x

Christman, K. (1998). The History of Chlorine. WaterWorld, 14, 66-67.

Clever, M., Jordt, F., Knauf, R., Räbiger, N., Rüdebusch, M., \& Hilker-Scheibel, R. (2000). Process Water Production from River Water by Filtration and Reverse Osmosis. Desalination, 131, 325-336. https://doi.org/10.1016/S0011-9164(00)90031-6

Den Hond, D., Schoeters, G., Koppen, G., Van Larebeke, N., Nelen, V., Bruckers, L., \& D'Hooghe, T. (2006). Relationship between PCBs, Dioxins, Chlorinated Pesticides, and Fertility Problems in Young Women. Epidemiology, 17, S193. https://doi.org/10.1097/00001648-200611001-00489

Despommier, D. D., Griffin, D. O., Gwadz, R. W., Hotez, P. J., \& Knirsch, C. A. (2019). Giardia Lamblia. In Parasitic Diseases (7th ed., pp. 11-20). New York: Parasites without Borders.

Dieter, C. A., \& Maupin, M. A. (2017). Public Supply and Domestic Water Use in the United States, 2015.

Environmental Protection Agency (EPA) (2016). Contaminant Candidate List (CCL) and Regulatory Determination. https://www.epa.gov/ccl/types-drinking-water-contaminants

Environmental Protection Agency (EPA) (2018). Ground Water and Drinking Water: National Primary Drinking Water Regulations.

https://www.epa.gov/ground-water-and-drinking-water/national-primary-drinking-wa ter-regulations\#Microorganisms

EPA, OA, OEAEE, OWC, US (1970). Reorganization Plan No. 3 of 1970. https://archive.epa.gov/epa/aboutepa/reorganization-plan-no-3-1970.html

EPA, Web Archives (2016). Reorganization Plan No. 3 of 1970. https://archive.epa.gov/epa/aboutepa/reorganization-plan-no-3-1970.html

Facking's Environmental Impacts: Water (2015). https://www.greenpeace.org/usa/global-warming/issues/fracking/environmental-impac ts-water

Feldman, R., \& White, R. (1992). Lead Neurotoxicity and Disorders of Learning. Journal of Child Neurology, 7, 354-359. https://doi.org/10.1177/088307389200700404

Flaten, T. (1992). Chlorination of Drinking Water and Cancer Incidence in Norway. International Journal of Epidemiology, 21, 6-15. https://doi.org/10.1093/ije/21.1.6

Gagnon, G. A., Rand, J. L., O’Leary, K. C., Rygel, A. C., Chauret, C., \& Andrews, R. C. (2005). Disinfectant Efficacy of Chlorite and Chlorine Dioxide in Drinking Water Biofilms. Water Research, 39, 1809-1817. https://doi.org/10.1016/j.watres.2005.02.004

Gandossi, L., \& Von Estorff, U. (2015). An Overview of Hydraulic Fracturing and Other Formation Stimulation Technologies for Shale Gas Production-Update 2015.

Guha, S., Harlin, P., \& Beni, R. (2019). The Effect of Trihalomethanes in Contaminating the Major Watershed of Middle Tennessee. Natural Science, 11, 233-245. https://doi.org/10.4236/ns.2019.117023

Hazen, A. (1916). Clean Water and How to Get It (p. 102). New York: Wiley.

Huisman, L., \& Wood, W. E. (1974). Filtration of Water Supplies. In Slow Sand Filtration (pp. 15-25). Geneva: World Health Organization.

Hwang, C., Ling, F., Erson, G., LeChevallier, M., \& Liu, W. T. (2012). Microbial Commu- 
nity Dynamics of an Urban Drinking Water Distribution System Subjected to Phases of Chloramination and Chlorination Treatments. Applied and Environmental Microbiology, 78, 7856-7865. https://doi.org/10.1128/AEM.01892-12

International Agency for Research on Cancer (1990). Chlorinated Drinking-Water, Chlorination By-Products, Some Other Halogenated Compounds, Cobalt Compounds. IARC Working Group on the Evaluation of Carcinogenic Risks to Humans: Chlorinated Drinking-Water, Lyon.

http://bases.bireme.br/cgi-bin/wxislind.exe/iah/online/?IsisScript=iah/iah.xis\&src=goo gle\&base $=$ WHOLIS\&lang $=$ p \&nextAction $=\operatorname{lnk} \& \operatorname{exprSearch}=9283212525 \&$ indexSearch $=\mathrm{ID}$

Jang, H. J., Choi, Y. J., \& Ka, J. O. (2011). Effects of Diverse Water Pipe Materials on Bacterial Communities and Water Quality in the Annular Reactor. Journal of Microbiology and Biotechnology, 21, 115-123. https://doi.org/10.4014/jmb.1010.10012

Jiang, J.-Q. (2015). The Role of Coagulation in Water Treatment. Current Opinion in Chemical Engineering, 8, 36-44. https://doi.org/10.1016/j.coche.2015.01.008

Kruithof, J., Kamp, P., \& Martijn, B. (2007). UV/H2O2 Treatment: A Practical Solution for Organic Contaminant Control and Primary Disinfection. The Journal of the International Ozone Association, 29, 273-280. https://doi.org/10.1080/01919510701459311

Kundzewics, Z. W., Kanae, E., Seneviratne, S. I., Handmer, J., Nicholls, N., Peduzzi, P., Mechler, R., Bouwer, L. M., Arnell, N., Mach, K., Muir-Wood, R., Brakenridge, G. R., Kron, W., Benito, G., Honda, Y., Takahashi, K., \& Sherstyukov, B. (2014). Flood Risk and Climate Change: Global and Regional Perspectives. Hydrological Sciences Journal, 59, 1-28. https://doi.org/10.1080/02626667.2013.857411

Laws, E. A. (2018). Aquatic Pollution: An Introductory Text (4th ed.). Hoboken, NJ: John Wiley.

Leal, J. L., Fuller, G. W., \& Johnson, G. A. (1909). The Sterilization Plant of the New Jersey City Water Supply Company at Boonton, N.J. In Proceedings American Water Works Association (pp. 100-109). Milwaukee.

LeChevallier, M. W., Lowry, C. D., Ramon, C. D., \& Gibbon, D. L. (1993). Examining the Relationship between Iron Corrosion and the Disinfection of Biofilm Bacteria. Journal $A W W A, 85,111-123$. https://doi.org/10.1002/j.1551-8833.1993.tb06031.x

Lenntech (2019). Turbidity: What Causes Turbidity. https://www.lenntech.com/turbidity.htm\#ixzz3R3yPreK7

Leoni, V., Fabiani, L., Marinelli, G., Puccetti, G., Tasitani, G., Carolis, A., Vascia, N., Morini, A., Aleandri, V., Pozzi, V., Cappa, F., \& Barbati, D. (1989). PCB and Other Organochlorine Compounds in Blood of Women with or without Miscarriage: A Hypothesis of Correlation. Ecotoxicology and Environmental Safety, 17, 1-11. https://doi.org/10.1016/0147-6513(89)90002-X

Malaeb, L., \& Ayoub, G. (2011). Reverse Osmosis Technology for Water Treatment: State of the Art Review. Desalination, 267, 1-8. https://doi.org/10.1016/j.desal.2010.09.001

McCoy, S., \& Van Briesen, J. (2012). Temporal Variability of Bacterial Diversity in a Chlorinated Drinking Water Distribution System. Journal of Environmental Engineering, 138, 786-795. https://doi.org/10.1061/(ASCE)EE.1943-7870.0000539

Morris, R., Audet, A., Angelillo, I., Chalmers, T., \& Mosteller, F. (1992). Chlorination, Chlorination By-Products, and Cancer: A Meta-Analysis. American Journal of Public Health Association, 82, 955-963. https://doi.org/10.2105/AJPH.82.7.955

National Drinking Water Clearinghouse (U.S.) (2000). Slow Sand Filtration. Tech Brief Fourteen. https://p2infohouse.org/ref/16/15369.pdf 
National Ground Water Association (NGWA) (2020). Hurricane Resources. https://www.ngwa.org/publications-and-news/Newsroom/news-and-updates/hurricane -resources

National Primary Drinking Water Regulations (NPDWR) (2017). Table of Regulated Drinking Water Contaminants. EPA.

https://www.epa.gov/ground-water-and-drinking-water/national-primary-drinking-wa ter-regulations

Nigg, J., Knottnerus, M., Martel, M., Nikolas, M., Cavanagh, K., Karmaus, W., \& Rappley, M. (2007). Low Blood Lead Levels Associated with Clinically Diagnosed AttentionDeficit/Hyperactivity Disorder and Mediated by Weak Cognitive Control. Biological Psychiatry, 63, 325-331. https://doi.org/10.1016/j.biopsych.2007.07.013

Niquette, P., Servias, P., \& Savoir, R. (2000). Impacts of Pipe Materials on Densities of Fixed Bacterial Biomass in a Drinking Water Distribution System. Water Research, 34, 1952-1956. https://doi.org/10.1016/S0043-1354(99)00307-3

Occupational Safety and Health Guideline for Chlorine Dioxide (OSHA) (2012). https://web.archive.org/web/20121204035804/http://www.osha.gov/SLTC/healthguideli nes/chlorinedioxide/recognition.html

Pathak, R., Mustafa, M., Ahmed, R., Tripathi, A., Guleria, K., \& Banerjee, B. (2009). Association between Recurrent Miscarriages and Organochlorine Pesticide Levels. Clinical Biochemistry, 43, 131-135. https://doi.org/10.1016/j.clinbiochem.2009.09.019

Pinto, A. J., Xi, C., \& Raskin, L. (2012). Bacterial Community Structure in the Drinking Water Microbiome Is Governed by Filtration Processes. Environmental Science and Technology, 46, 8851-8859. https://doi.org/10.1021/es302042t

PubChem (2019). Potassium Permanganate. https://pubchem.ncbi.nlm.nih.gov//\#query=Potassium-permanganate

Ramsay, C., Wagner, A., Robertson, C., Smith, H., \& Pollock, K. (2014). Effects of Drinking-Water Filtration on Cryptosporidium Seroepidemiology, Scotland. Emerging Infectious Diseases, 20, 71-78. https://doi.org/10.3201/eid2001.120386

Rinde, M. (2017). Richard Nixon and the Rise of American Environmentalism. Distillations, 3, 16-29.

https://www.sciencehistory.org/distillations/richard-nixon-and-the-rise-of-american-e nvironmentalism

Sanches, S., Crespo, M., \& Pereira, V. (2009). Drinking Water Treatment of Priority Pesticides Using Low Pressure UV Photolysis and Advanced Oxidation Processes. Water Research, 44, 1809-1818. https://doi.org/10.1016/j.watres.2009.12.001

SDWA (2017). Background on Drinking Water Standards in the Safe Drinking Water Act. Washington DC: U.S. Environmental Protection Agency (EPA). https://www.epa.gov/dwstandardsregulations/background-drinking-water-standards-s afe-drinking-water-act-sdwa

Simpson, D. (2008). Biofilm Processes in Biologically Active Carbon Water Purification. Water Research, 72, 2839-2848. https://doi.org/10.1016/j.watres.2008.02.025

Sponseller, J. K., Griffiths, J. K., \& Tzipori, S. (2014). The Evolution of Respiratory Cryptosporidiosis: Evidence for Transmission by Inhalation. Clinical Microbiology Reviews, 27, 575-586. https://doi.org/10.1128/CMR.00115-13

Szewzyk, U., Szewzyk, R., Manz, W., \& Schleifer, K.-H. (2000). Microbiological Safety of Drinking Water. Annual Review of Microbiology, 54, 81-127.

https://doi.org/10.1146/annurev.micro.54.1.81

Turneaure, F., \& Russell, H. L. (1901). Public Water-Supplies: Requirements, Resources, and the Construction of Works (p. 493). New York: John Wiley\& Sons. 
U.S. Army Public Health Command (2011). Ultraviolet Light Disinfection in the Use of Individual Water Purification Devices.

https://phc.amedd.army.mil/PHC\%20Resource\%20Library/Ultraviolet\%20Light\%20Disinfe ction\%20in\%20the\%20Use\%20of\%20Individual\%20Water\%20Purification\%20Devices.pdf

United States FDA, United States Federal Food, Drug, and Cosmetic Act (FDA) (1938). 21 U.S. Code S 301. Short Title. https://www.law.cornell.edu/uscode/text/21/301

US EPA, United States Environmental Protection Agency (1990). Technologies for Upgrading Existing or Designing New Drinking Water Treatment Facilities. https://nepis.epa.gov/Exe/tiff2png.cgi/300048WU.PNG?-r+75+-g+7+D\%3A\%5CZYFIL ES\%5CINDEX\%20DATA\%5C86THRU90\%5CTIFF\%5C00000542\%5C300048WU.TIF

US EPA, United States Environmental Protection Agency (2019). EPA's Budget and Spending. https://www.epa.gov/planandbudget/budget

US EPA, United States EPA (2018). 2018 Edition of the Drinking Water Standards and Health Advisories Tables. https://www.epa.gov/sites/production/files/2018-03/documents/dwtable2018.pdf

Van Der Kooij, D., Vrouwenvelder, H. S., \& Veenendaal, H. R. (1995). Density and Composition of Biofilms in Drinking Water Distribution Systems in the Netherlands. Proc. AWWA Water Quality Technology Conference, New Orleans, 12-16 November 1995 1055-1062.

Wang, H., Masters, S., Edwards, M., Falkinham, J., \& Pruden, A. (2014). Effect of Disinfectant, Water Age, and Pipe Materials on Bacterial and Eukaryotic Community Structure in Drinking Water Biofilm. Environmental Science and Technology, 48, 14261435. https://doi.org/10.1021/es402636u

WHO World Health Organization (2007). Legionella and the Prevention of Legionellosis. https://www.who.int/water sanitation health/emerging/legionella.pdf

WHO World Health Organization (2017). Water Quality and Health-Review of Turbidity: Information for Regulators and Waste Water Supplies.

https://www.who.int/water sanitation health/publications/turbidity-information-2002 17.pdf

Wilhite, C., Bhat, V., Ball, G., \& McLellan, C. (2012). Emergency Do Not Consume/Do Not Use Concentrations for Potassium Permanganate in Drinking Water. Human and Experimental Toxicology, 32, 275-298. https://doi.org/10.1177/0960327112456316

Yang, C., Chiu, H., Cheng, M., \& Tsai, S. (1998). Chlorination of Drinking Water and Cancer Mortality in Taiwan. Environmental Research, 78, 1-6. https://doi.org/10.1006/enrs.1997.3823

Yousef, S., Eapen, V., Zoubeidi, T., Kosanovic, M., Mabrouk, A., \& Adem, A. (2013). Learning Disorder and Blood Concentration of Heavy Metals in the United Arab Emirates. Asian Journal of Psychiatry, 6, 394-400. https://doi.org/10.1016/j.ajp.2013.04.005

Yu, J., Kim, D., \& Lee, T. (2010). Microbial Diversity in Biofilms on Water Distribution Pipes of Different Materials. Water Science and Technology, 61, 163-171. https://doi.org/10.2166/wst.2010.813

Zimmer, J. L., \& Slawson, R. M. (2002). Potential Repair of Escherichia coli DNA Following Exposure to UV Radiation from Both Medium- and Low-Pressure UV Sources Used in Drinking Water Treatment. Applied and Environmental Microbiology, 68, 3293-3299. https://doi.org/10.1128/AEM.68.7.3293-3299.2002 